\title{
Overdoser som selvmord: en fenomenologisk case studie
}

Ved Stian Biong

\begin{abstract}
Noen overdosedødsfall kan være selvmord. To slike situasjoner analyseres i denne studien. Livsomstendighetene det siste året var preget av stadige kriser, negative fysiske forandringer, endrede relasjoner til andre og seg selv, samt av mangel på tilgang til hjelp som svarte til behovene. Studien antyder viktigheten av at fagfolk inntar en deltakerposisjon i forhold til personer med rusproblemer og bidrar til å skape håp.
\end{abstract}

\begin{abstract}
Forskningslitteraturen dokumenterer at noen overdosedødsfall kan være selvmord. Denne studien baserer seg på data fra en gjennomgang av alle registrerte overdosedødsfall i Oslo i perioden 2006-2008. Med utgangspunkt i et case bestående av to av disse dødsfallene som ble vurdert å være selvmord enten på bakgrunn av spesifikke uttalelser eller avskjedsbrev, beskriver den hvordan pårørende og fagfolk erfarte de avdødes livsomstendigheter siste året de levde. Fenomenet overdoser som selvmord belyses også med erfaringer fra andre deltakere i Oslo-gjennomgangen. Gjennom en kvalitativ analyse fremkom fem forhold av betydning for overdoser som selvmord. Forholdene drøftes i lys av to av prinsippene fra Ottawa-erklæringen om å fremme helse. Konklusjonen antyder viktigheten av å innta en deltakerposisjon i forhold til personenes livsomstendigheter og betydningen av å skape håp.
\end{abstract}

In the research literature there is documentation that some overdose deaths may be suicide. This study is based on data from a review of all fatal overdoses in Oslo during the period 2006-2008. Based on a case comprising two of these deaths that were assumed to be suicide, either based on specific statements or suicide notes, we describe how relatives and professionals experienced the deceased persons' life situation during the last year they lived. The phenomenon of overdose as suicide is also illustrated using the experiences of other participants in the Oslo study group. Using qualitative analysis, we found five important elements for overdose as suicide. These are discussed in the light of two of the principles for health promotion in the Ottawa declaration. We suggest the importance of taking on a participant-position in relation to the persons' life contexts and the meaning of creating hope.

\section{Bakgrunn}

Denne artikkelen baserer seg på data fra en gjennomgang av alle registrerte overdosedødsfall i Oslo i perioden 2006-2008 (Gjersing et al., 2011). Tilsammen 232 personer under 70 år døde av overdose $\mathrm{i}$ perioden. Registerdelen av gjennomgangen viste at $93 \%$ ble obdusert og at 14 dødsfall hadde blitt kodet som selvmord i Dødsårsaksregisteret. I den kvalitative delen ble livsomstendighetene det siste året til åtte avdøde belyst gjennom intervjuer med pårørende og helse- og sosialarbeidere som hadde deltatt i oppfølging og behandling (heretter kalt fagfolk). To av disse åtte dødsfallene ble vurdert å være selvmord, enten på bakgrunn av spesifikke uttalelser i tiden like før dødsfallet, eller ved funn av avskjedsbrev. Retterstøl et al. $(2002$, s. 221) Iøfter fram at $70-80 \%$ av dem som tar sitt eget liv har varslet på forhånd. Det er derfor lagt til grunn at pårørende og fagfolks antakelser om selvmord i disse to tilfellene stemmer. European Monitoring Centre for Drugs and Drug Addiction rapporterer at dødsfall ved narkotikaproblemer utgjør et økende folkehelseproblem i Europa (EMCDDA, 2011). Det vises til at mortaliteten blant personer med denne typen rusproblemer er 10-20 ganger høyere enn for den generelle befolkningen, og at mellom 6500 og 8500 personer med narkotikaproblemer dør av overdoser hvert år i verdensdelen (ibid, s. 11). Et overdosedødsfall er av EMCDDA (2009) definert som et dødsfall som skjer kort tid etter inntak av ett eller flere rusmidler eller medikamenter og er direkte relatert til dette inntaket. Praksisen knyttet til injisering av heroin står for størstedelen av disse dødsfallene (Hickman et al., 2007). Dark og medarbeidere fant $i$ en litteraturgjennomgang at mellom
$17 \%$ og $45 \%$ av personer med narkotikaproblemer hadde gjennomført selvmordsforsøk, men heroin ser ut til å spille en mindre rolle enn andre rusmidler og medikamenter i selvmord i denne gruppen (Darke et al., 2007a,b). Selvmord er beregnet å utgjøre 10-20\% av dødsfallene blant personer med narkotikaavhengighet (EMCDDA, 2011). Risikofaktorer som kjønn (mann), psykiske lidelser, tidligere selvmordsfors $ø \mathrm{k}$ og sosial isolasjon synes også å gjelde ved selvmord gjennom overdose, og det ser ut til at selvmordsrisikoen er størst hos yngre (Oyefeso et al., 1999). Opplevelse av traumatiske hendelser ser ut til å være av betydning (Mills et al., 2005). Hensikten med denne studien er å undersøke og belyse forhold av betydning knyttet til overdoser som selvmord. Følgende forskningsspørsmål ble formulert:

Hvordan beskriver pårørende og fagfolk livsomstendighetene det siste året til personer som døde av overdose som ble antatt å voere selvmord?

\section{Metode}

Studien har et eksplorativt og deskriptivt design. Det vitenskapsteoretiske grunnlaget er en fenomenologisk tilnærming (Husserl, 1989) som handler om å skape kunnskap om ontologisk subjektive fenomener. Yin (2014) peker på at både singlecase og multiple-casestudier er egnet til å belyse sammensatte forhold der det kan være vanskelig å skille fenomenet fra konteksten. Siden fenomenet er vist å være relatert til kontekstuelle og individuelle faktorer, ble casestudie vurdert som relevant å gjennomføre for å besvare forskningsspørsmålet (Gjersing et al., 2011). I suicidologisk forskning er både singlecase og multiple-casestudier anvendt tidligere (Michel et al., 2002; Biong \&t Svensson, 2009). Valget av multiple-case i denne 
studien var knyttet til ønsket om å undersøke begge de to dødsfallene som i den kvalitative delen ble antatt å være selvmord.

\section{Utvalg}

Caset består av én kvinne og én mann, begge i tjueårene. Kvinnen hadde hatt en oppvekst preget av psykososiale problemer, mens mannen ble beskrevet som å ha vokst opp i et nokså vanlig hjem, men i et annet land og med skilte foreldre. Begge hadde hatt et langvarig blandingsmisbruk med injisering av heroin fra de var ca.15 år gamle, og hadde vært i behandling for rusproblemene sine. Begge hadde hatt tidligere overdoser. For den ene inneholdt behandlingen opphold $i$ langtidsinstitusjon og oppfølging i kommunale lavterskelinstitusjoner. For begge var legemiddelassistert rehabilitering under planlegging eller oppstart. De hadde vært innlagt til avrusning i løpet av de siste tre månedene før dødsfallet. Av personvernhensyn ble det ikke spurt etter eventuelle diagnoser under intervjuet. Pårørende og fagfolk visste ikke om selvmordsrisiko var kartlagt under avrusningen. Kvinnen hadde ikke hatt fast arbeid, lønnsinntekt eller egen bolig, og hun hadde lengre fengselserfaring. Mannen hadde hatt lengre rusfrie perioder med arbeid, lønnsinntekt og bolig. Han hadde ikke vært fengslet. For en redegjørelse om det totale utvalget og rekrutteringen henvises det til Gjersing et al. (2011).

\section{Datainnsamling}

Data om de avdøde i caset ble henholdsvis gitt av pårørende (kjæreste) eller primærkontakt, sosialkonsulent og lege i ruspoliklinikk gjennom individuelle forskningsintervjuer (Kvale \& Brinkmann, 2009). Deltakerne ble rekruttert via pårørendegrupper eller faglige tiltak. Intervjuene ble gjennomført av undertegnede og der deltakerne selv ønsket. Med hensyn til studiens eksplorative og deskriptive design ble intervjuene strukturert rundt ett åpningsspørsmål: Kan du fortelle om hvordan du erfarte livsomstendighetene til $x x$ det siste året hun/han levde? Hensikten var at deltakerne skulle få komme frem

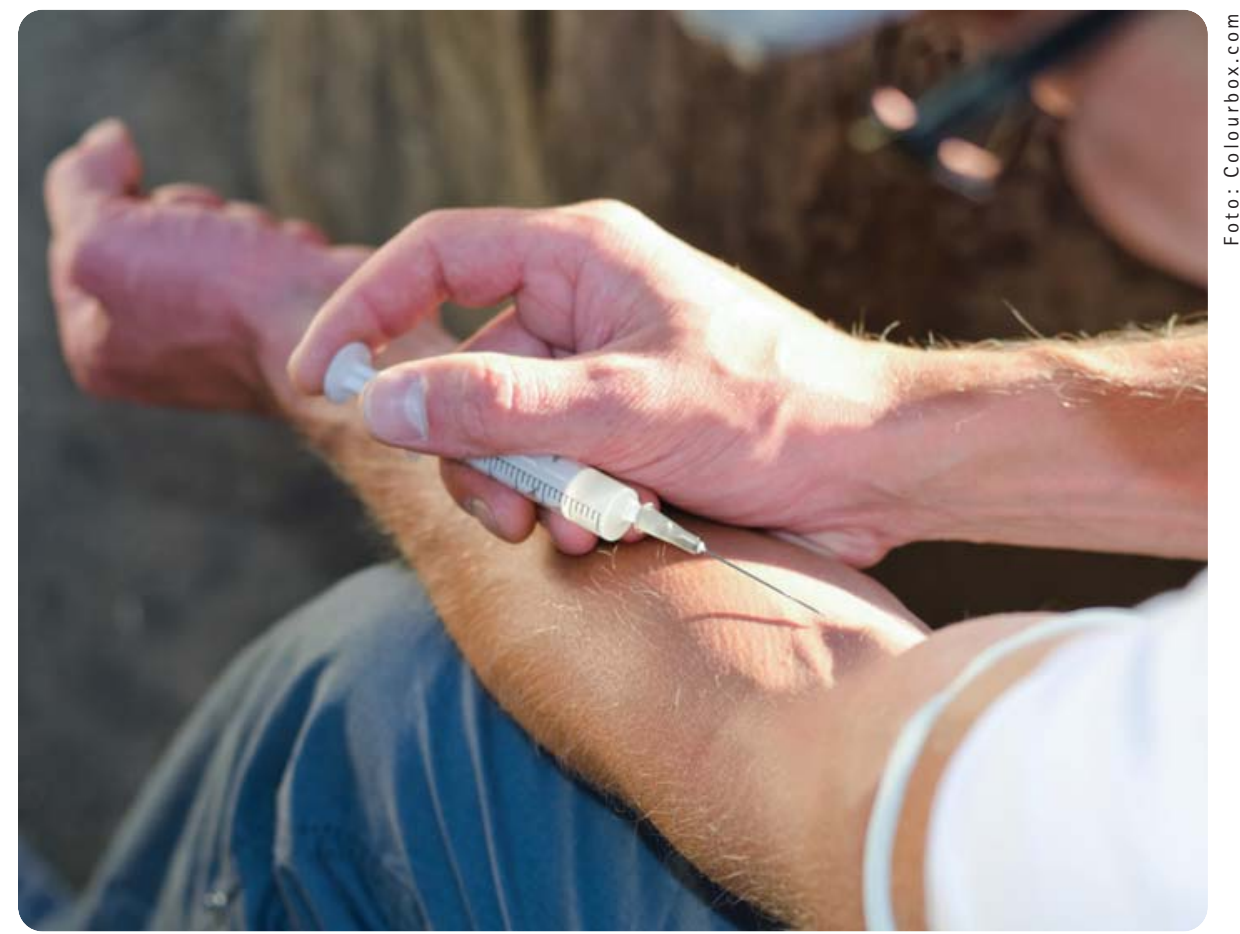

med så mange av sine erfaringer som mulig. Intervjuene ble tatt opp på bånd, og transkribert ord for ord. Forskningsspørsmålet belyses også med data fra noen andre deltakere i Oslo-gjennomgangen der dette ble vurdert å være relevant.

\section{Dataanalyse}

Med utgangspunkt i forskningsspørsmålet er det i analysen av data anvendt systematisk tekstkondensering (Malterud, 2012). Metoden er egnet for en eksplorativ og deskriptiv analyse av et fenomen som beskrives fra flere ulike deltakere, og for å kunne utvikle nye beskrivelser av fenomenet så tekstnært som mulig. En systematisk tekstkondensering foregår i en prosess med fire trinn: 1) å få et helhetsinntrykk, 2) å identifisere meningsbærende enheter, 3) å abstrahere innholdet i enhetene og 4) å sammenfatte betydningen i nye beskrivelser.

\section{Forskningsetikk}

Studien ble på forhånd godkjent av Regional komité for medisinsk og helsefaglig forskning Sør Øst, og gjennomføringen har vært i tråd med denne. Før intervjuet tok til ble samtykkeerklæring underskrevet. Med hensyn til kravet om konfidensi- alitet er det i fremstillingen av data lagt vekt på å hindre at noen gjenkjennes. I informasjonsskrivet ble det redegjort for hvordan deltakerne kunne få hjelp hvis intervjusituasjonen førte til ulemper.

\section{Funn}

Pårørende og fagfolk beskrev generelt tre ulike typer overdosedødsfall; "uhell" (uventede), "ble ikke overrasket" (krisesituasjoner) og "å komme til veis ende" (antatt selvmord).

Livsomstendighetene det siste året for personene i caset ble beskrevet som preget av sterkt vekslende og negative hendelser psykososialt, fysisk og eksistensielt. Ved hjelp av den systematiske tekstkondenseringen ble det mulig å utvikle fem nye beskrivelser om hva livsomstendighetene hadde handlet om: Fare på ferde hele tiden, fysiske forandringer, signaliserte avstand, forholdt seg annerledes til liv og død og overdoser er mer enn et uhell.

\section{Fare på ferde hele tiden}

Fagfolkene beskrev at livsomstendighetene for kvinnen i caset siste året var preget av mange og ulike kriser. At omtendighetene var krisepreget over så lang tid kunne i følge primærkontakten med- 
føre at fagfolk ikke klarte å ta inn over seg alvoret: "Det er fare på ferde hele tiden. Det har vaert så mange røde lamper at man ikke klarte å se når det faktisk var farlig." Primærkontakten beskrev at krisene medførte at avdøde hadde bedt om hjelp, men på en slik måte at omgivelsene ikke forsto det: "Hun ropte på hjelp, men aldri uttalt." Sosialkonsulenten beskrev likevel mer eksplisitte rop om hjelp: "Hun snakket om sin egen død. Det var utfordrende å høre på." Et annet forhold var at handlingsmønsteret til vedkommende endret seg rett før dødsfallet. Primærkontakten fortalte: "De siste dagene møtte hun opp på tidspunkter da kontaktpersonene ikke hadde mulighet til å snakke med henne. Den roen hun hadde, mistenker jeg i ettertid, var en ro over å ha funnet ut av at om klarer jeg ikke å vœre rusfri denne gangen her, så gjør jeg det slutt. At hun hadde bestemt seg." Pågående krise kunne også vise seg også i form av et høyt omfang av livstruende overdoser på kort tid. En av personene med egenerfaring beskrev tre overdoser hos kjæresten på tre dager: "Det var ikke uhell, men et rop om hjelp." At det var fare på ferde hele tiden så ut til å gjøre det problematisk å reagere også på fysiske forandringer som utviklet seg over tid, og som kunne indikere en negativ utvikling.

\section{Fysiske forandringer}

For begge personer i caset ble det beskrevet negative fysiske forandringer siste året. Pårørende fortalte: "Han hadde en alvorlig infeksjon. Dagen før han døde hadde han ringt legen og spurt. Han var veldig nervøs og ville ikke leve. Det var på torsdag. Fredag fant jeg ham død." Legen i ruspoliklinikken beskrev de fysiske endringene for kvinnen i caset slik: "Hun hadde veldig sterk hoste. Jeg lyttet på henne, det gjør man ikke så ofte her. Jeg husker hvordan hun så ut og at det gjorde så sterkt inntrykk. Jeg tenkte på hvordan hun måtte ha det." Primærkontakten trakk fram: "Da hun døde, bar hun preg av at det bare ble verre og verre. Begynte å se på henne at hun hadde brent masse broer." En ambulansemedarbeider fortalte om hvordan de observerte negative fysiske forandringer, og hvilke konsekvenser disse kunne ha: "Folk som er slitne er lett å se. Ansiktsuttrykket, hudfargen, slappe øyne. Du ser at de er i en kritisk fase. Er du fysisk sliten blir du psykisk sliten óg." (Ambulansemedarbeider 2). Beskrivelsene her tydet på at fysiske forandringer også kunne henge sammen med, og innvirke på, forverring av eksistensielle og relasjonelle forhold.

\section{Signaliserte avstand}

Relasjonene mellom de avdøde og de rundt dem endret seg det siste året. Legen til kvinnen i caset erfarte at relasjonene dem imellom ble vanskeligere, fordi vedkommende signaliserte avstand: "Fra den siste timen forsto jeg det slik at hun ville ha meg litt på avstand. "Sosialkonsulenten fortalte at vedkommende uteble til avtalene mellom dem den siste måneden før dødsfallet. Brudd i nære relasjoner utgjorde en vesentlig del av endringene i relasjonene like før dødsfallet: "Dagen hun døde hadde hun hatt en stor krangel med kjaresten. Det var ikke en feildosering. Det var et brev til moren i lommeboka om hvordan begravelsen skulle vœre." (Primærkontakt). Overdoser med intensjon om å dø kunne på den annen side skape en slags øyeblikks-nærhet til fagfolk, forutsatt at muligheten ble brukt: "Jeg har opplevd folk som ville dø av overdosen. Om det kom fram er avhengig av om vi prøver å spørre de litt og komme under huden." (Ambulansemedarbeider 1).

\section{Forholdt seg annerledes til liv og død}

Relasjonen de avdøde hadde hatt til seg selv ble også oppfattet som endret. Primærkontakten for kvinnen i caset beskrev det slik: "...du har gått over alle terskler og forholder deg annerledes til liv og død. Hun forsøkte hele tiden, fikk seg kjareste, prøvde å lage $C V$, søke jobber. Hun så vel i større grad hvor dårlig stilt hun var i forhold til det normale livet. Og jo narmere hun kom det normale livet, dess verre syns hun selv at hun var." Pårørende til mannen i caset fortalte om at hun også opplevde at de stadige krisene endret forholdet han hadde til seg selv: "Han hadde det dårlig (med seg selv). Mistet jobben. Han ... ville vœre frisk, men så gikk det rett ned." Hun fortalte at avdøde i forbindelse med endringene i relasjonen til seg selv ville avbryte forholdet med henne. Han hadde sagt: "Just leave me and go. Det er slutt." Dette skjedde omlag én måned før han døde, samtidig som han hadde vært innlagt etter en overdose. De endrede og negative livsomstendighetene så ut til å ha betydning for behovet for hjelp.

\section{Overdoser er mer enn et uhell}

Pårørende til mannen i caset fortalte om to tidligere overdoser hvor hun opplevde at han ikke hadde fått den hjelpen hun mente han trengte: "De (AMK) spurte hva som hadde skjedd. Jeg sa han hadde brukt heroin og pustet dårlig, kan dere komme? Nei, vi kommer ikke til narkomane, svarte de. Gjør han vold mot deg, så kan politiet komme. Neste gang sa de at Oppsøkende skulle komme. De kom etter ti minutter, og han ble med til Legevakten. Jeg satt på gulvet i seks-syv timer. Så kom legen og tok pulsen hans. Den var ok. Dere kan gå hjem, sa han." Et annet forhold som hadde betydning for å yte hjelp i tråd med behovene var i følge primærkontakten til kvinnen i caset at: "Saksbehandlerne klarer i liten grad å forholde seg til overdoseproblematikk og hva rusmisbruk betyr. Det tror jeg sosialtjenesten er dårlig på."Hjelp som i følge personene med egenerfaring kunne bidra til å forebygge overdosedødsfall generelt var "å få treffe en lege i forbindelse med den forste overdosen." De trakk fram at hjelpen dessuten måtte strekke seg utover den akuttmedisinske behandlingen, fordi: "En overdose er nesten alltid mer enn et uhell" (Mann, hybelhus). Dette sto i kontrast til hvordan en av ambulansemedarbeiderne beskrev den hjelpen de kunne gi: "Vi ivaretar de livsviktige funksjonene og har nok ikke tid til å sitte et kvarter med hver overdose." (Ambulansemedarbeider 1). På den annen side beskrev ambulansemedarbeider 2 at: "Pasienter med selvmordsforsøk skal minimum til Legevakt og følges opp med psykiatrisk vakttjeneste. Det er det som avviker fullstendig fra overdosene." 


\section{Diskusjon}

Hensikten med denne studien er å undersøke forhold av betydning knyttet til overdoser som selvmord. Metodisk har den flere svakheter. Det empiriske materialet omhandler en lang tidsperiode. En kortere periode kunne gitt mer relevant informasjon. Utvalget var hensiktsmessig og vanskeliggjør sammenlikninger. Det er begrensninger i overførbarheten. Selv med utsagn om selvmordsnærhet og avskjedsbrev, kan det ikke med sikkerhet fastslås at intensjonene i dødsfallene var selvmord. Studien kan ha relevans gjennom å belyse kompleksiteten i livsomstendighetene og å underbygge behovet for å løfte fram innsideperspektivet. Reliabiliteten er ivaretatt ved bruk av en relevant analysemetode i forhold til forskningsspørsmålet, samt at kodegruppene bekreftes i data. En begrensning er at studien er foretatt av én forsker.

Hovedfunnet i studien (kodegruppene) antyder både strukturelle, kulturelle og individuelle forhold av betydning det siste året. Dette antyder nødvendigheten av en bred tilnærming og helhetlig forståelse. Et helsefremmende perspektiv i tråd med Ottawa-erklæringens prinsipper (WHO, 1986) antas å bidra til et mer helhetlig fokus. Det er prinsippene om "å skape støttende miljøer" og "å utvikle personlige ferdigheter" som synes å være mest relevant for drøftingen av empirien i denne studien.

Studien kan ikke si noe generelt om kvalitet og omfang på den hjelpen som ble gitt i forhold til livsomstendighetene siste året. Empirien antyder strukturelle forhold som kunne bidra til diskrepans mellom behov, etterspørsel og tilbud. Dette handler for eksempel om at sosialtjenesten av seg selv ikke etterspurte erfaringer med overdoser. Et annet er de prehospitale tjenestenes oppgaveforståelse og tilgang til lege i overdosesituasjoner.

Ambulansens behandlingstid er i en nylig studie fra Oslo vist å være knapt 17 minutter og at nesten $83 \%$ forlates på stedet (Alstadius \& Rossow, 2013).

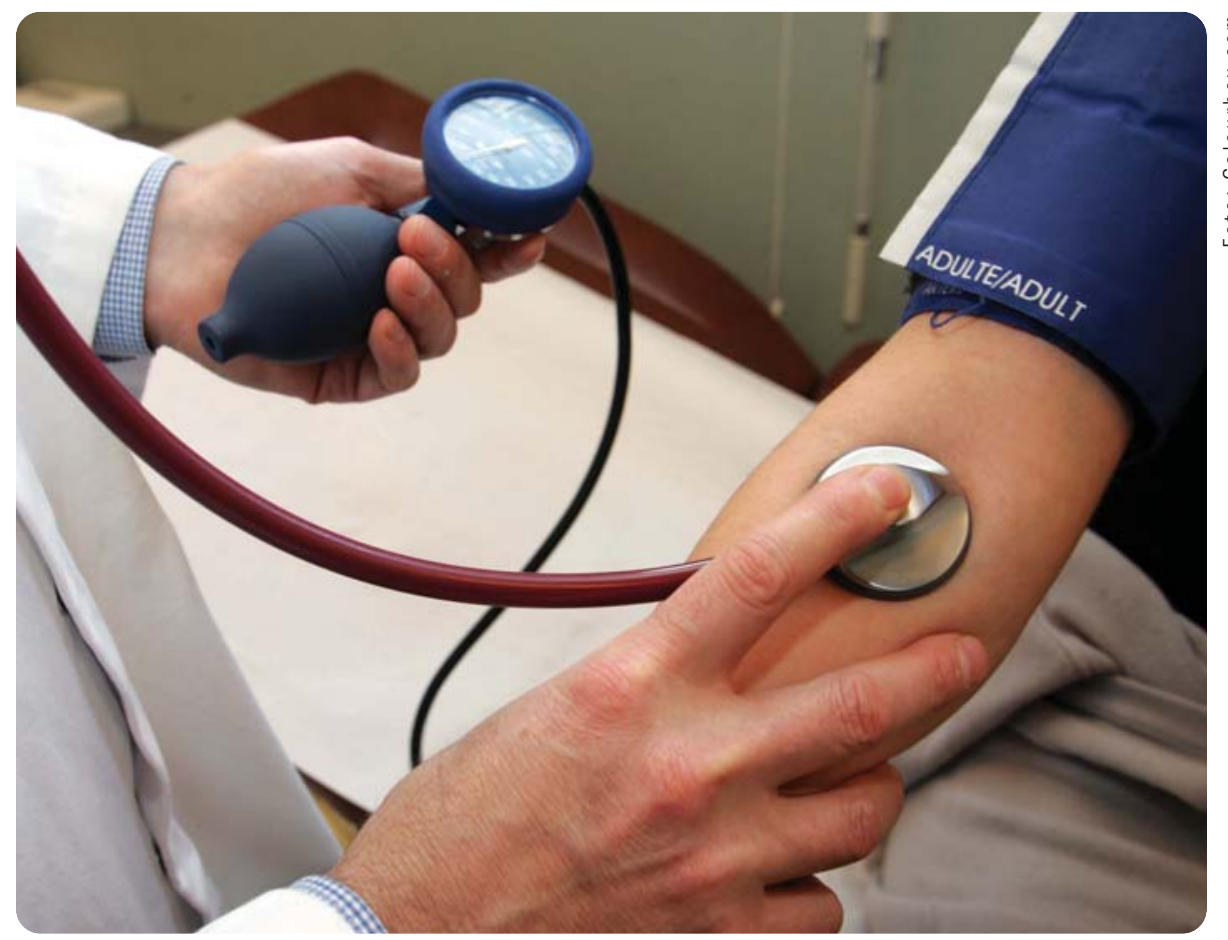

Med tanke på behovene for kartlegging og vurdering av overdoseerfaringer eller selvmordsrisiko er dette strukturelle forhold som ikke synes å underbygge en helhetlig tilnærming. Personer med egenerfaring fra overdoser ønsket å komme til lege ved første overdose, fordi slike situasjoner slik de ser det ofte er mer enn et uhell. Strukturelle problemer som tidsnød eller tjenestenes mandater kan her komme i tillegg til de problemene en person som reddes fra overdose av ulike grunner kan ha med å formulere egne behov i akuttsituasjonen (Biong \& Svensson, 2009).

Empirien antyder også at personene i caset endret adferd, signaliserte avstand eller selv brøt relasjonene til fagfolkene. På grunn av psykologisk motstand eller andre forhold hos vedkommende kan da fagfolk hindres i å skape et støttende miljø.

Strukturelle forhold kan også inkludere kulturelle forhold. Möller-Leimkühler (2003) og Scourfield (2005) peker på at kulturelle idealer om maskulinitet som for eksempel autonomi og kontroll kan begrense menns sosiale muligheter for å be om hjelp. Kulturelle idealer påvirker også kvinner med rusproblemer (Trulsson, 2004).
Empirien antyder at begge personene $\mathrm{i}$ caset, om enn i ulik grad, signaliserte problemer med å leve opp til kulturelle idealer i form av rusfrihet, arbeid og nære relasjoner. En faglig utfordring etter vår erfaring blir da å skape støttende miljøer som likevel bidrar til en opplevelse av mestring, samt å belyse andre verdifulle personlige egenskaper og ressurser. Empirien tyder på at det er viktig at fagfolk forstår overdoser også som kommunikasjon om konkrete, livshistoriske situasjoner. Ved å utvikle sine personlige ferdigheter til å få en større forståelse av "innsideperspektivet" kan fagfolk få tilgang til den virkeligheten og de meningssystemer personen selv forholder seg til og handler ut fra (Michel et al., 2002; Hammerlin, 2010). Den vedvarende krisesituasjonen og et tilsynelatende endret forhold til seg selv, andre og til spørsmålet om liv og død synes å gjøre dette ekstra utfordrende. Dette dreier seg også om i hvilken grad fagfolk evner å ivareta og videreutvikle sine ferdigheter til å stå i etisk vanskelige problemstillinger når det er fare på ferde nærmest hele tiden. En annen utfordring er knyttet til å reagere på kroppslige eller språklige uttrykk som 
representerer vedkommendes meningssystemer (Kirkengen, 2000; Beskow et al., 2005; Biong et al., 2008). A la forandringer i livsomstendighetene på de fem områdene som er beskrevet her få gjøre inntrykk hos fagfolk, samt å følge dem opp, kan sies å la sin praksis være inspirert av Skjervheims (1976) idé om å være deltaker (subjekt) mer enn tilskuer (objekt). Skjervheim beskriver deltakerposisjonen som en treleddet relasjon; mellom meg, den andre og "saken" (problemet). I en slik relasjon kan fagfolks og personen som har behov for hjelp sitt kunnskapsgrunnlag bli mer likeverdig. Partene kan utvikle en felles forståelse av livsomstendighetene, slik Michel et al. (2002) etterlyser. Empirien gir eksempler på at både fagfolk og personer med alvorlige rusproblemer kan komme til å innta, eller bli tildelt, en tilskuerposisjon. Arbeidsløshet, gjentatte overdoser og fysisk sykdom kunne ha bidratt til dette for mannen. For kvinnen kan en økende opplevelse av å være sosialt død gjennom å mislykkes i det normale livet, slik primærkontakten antydet, ha medvirket. Kriser kan defineres som situasjoner hvor tidligere erfaringer og lærte reaksjoner ikke er tilstrekkelige for å forstå og mestre livsomstendighetene (Cullberg, 1978). Da kan fagfolks evner til å skape håp være viktige personlige ferdigheter. En tidligere studie viste at pasienter i svært pressende livsomstendigheter beskrev håp i relasjonelle termer, og at mange av beskrivelsene av håp var udefinerte, det vil si vage, og uten konkretiseringer av hva som skulle skje, når og hvem som skulle bidra (Herrestad \& Biong, 2010). Vi framsatte en hypotese om at slike håp likevel kan være verdifulle for pasienten, fordi udefinerte håp kan beskytte mot ytterligere opplevelse av skuffelser. Å arbeide med håp og håpefullhet som utgangspunkt hos pasienter med rus- og selvmordsadferd krever utvikling av personlige egenskaper hos fagfolk. Empirien tyder på at fagfolk i slike situasjoner må fokusere og håndtere individuelle, kulturelle og strukturelle forhold samtidig, for stadig å lete etter hva som kan tilrettelegges for pasienten og inspirere vedkommende til å ville leve.

\section{Konklusjon}

Livsomstendighetene siste året for personene i caset ble beskrevet som krisepreget og med negative fysiske forandringer, endrede relasjoner til andre og seg selv, samt tilgang til hjelp som ikke alltid svarte til behovene. Overdoser ble under slike forhold beskrevet som mer enn et uhell. Langvarig krise, kombinert med spesialiserte mandater i tjenestene, kan gjøre relasjons- og hjelpearbeidet utfordrende. Faglige utfordringer synes å være knyttet til mangel på kartlegging av overdoser i sosialtjenesten og av selvmordsrisiko ved den akuttmedisinske behandlingen, samt til manglende tilgang til lege. Studien antyder viktigheten av en deltakerposisjon i forhold til personenes livsomstendigheter og betydningen av at fagfolk bidrar til å skape håp.

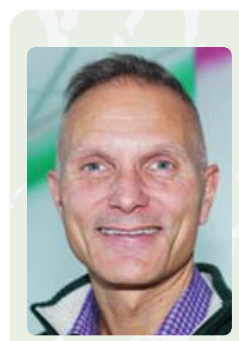

Stian Biong er sykepleier og folkehelseviter. Han arbeider som forsker ved Senter for rus- og avhengighetsforskning, UiO. Hans hovedstilling er som professor i psykisk helsearbeid ved Høgskolen i Buskerud, Senter for psykisk helse og rus.

\section{Referanser}

Alstadius, S., \& Rossow, I. (2013). Tidsbruk ved behandling av overdoser i Oslo. Sykepleien Forskning; 8 (3): 200-208.

Beskow, J., Beskow, A.P., \& Ehnvall, A. (2005). Suicidalitetens språk. Lund: Studentlitteratur.

Biong, S., Karlsson, B., \& Svensson, T. (2008). Metaphors of a shifting sense of self in men recovering from substance abuse and suicidal behavior. J Psychosoc Nurs Ment Health Serv; 46 (4): 35-41.

Biong, S., \& Svensson, T. (2009). Bridging the gaps. Experiencing and preventing life-threatening heroin overdoses in men in Oslo. Int J Qual Stud Health and Well-being; 4: 94-105.

Cullberg, J. (1978). Mennesket i krise og utvikling. Oslo: Aschehoug.

Darke, S., Degenhardt, L, \&t Mattick, R. (2007a). Mortality amongst illicit drug users: epidemiology, causes and interventions. Cambrigde: Cambridge University Press.

Darke, S., Duflou, J., \&t Kaye, S. (2007b). Comparative toxicology of fatal heroin overdose cases and morphine positive homicide victims. Addiction; 102 (11): 1793-1797.

European Monitoring Centre for Drugs and Drug Addiction. (2009). Drug-related deaths and mortality (DRD). Lisbon: European Monitoring Centre for Drugs and Drug Addiction.
European Monitoring Centre for Drugs and Drug Addiction. (2011). Mortality related to drug use in Europe: Public health implications. Luxembourg: Publications Office of the European Union.

Gjersing, L., Biong, S., Ravndal, E., Waal, H., Bramness, J., \& Clausen, T. (2011). Dødelige overdoser i Oslo. En helhetlig gjennomgang. Oslo: Senter for rus- og avhengighetsforskning, Universitetet i Oslo. Hammerlin, Y. (2010). Samfunnets og hverdags-livets lidelsesproduksjon og selvmordsproblematikken. Ansatser til en kritisk refleksjon. Suicidologi; 15 (2): 30-36.

Herrestad, H. \& Biong, S. (2010). Relational hopes: A study of the lived experiences of hope in some patients hospitalized for intentional self harm. Int $J$ of Qual Studies on Health and Well-being; 5 (1): 1-9 (DOI: 10.3402/qhw.v5il.4651).

Hickman, M., Carrivick, S., Paterson, S., Hunt, N., Zador, D., Cusick, L., \& Henry, J. (2007). London audit of drug-related overdose deaths: characteristics and typology, and implications for prevention and monitoring. Addiction; 102: 317-323.

Husserl, E. (1989). Fenomenologins idé. Göteborg: Daidalos.

Kirkengen, A.L. (2000). Innskrevet i kroppen. Tidsskrift for Den Norske Legeforening: 13: 120-124.

Kvale, S. \& Brinkmann, S. (2009). InterView. Introduktion til et håndværk. (2. utgave). København: Hans Reitzels Forlag.

Malterud, K. (2012). Systematic text condensation: A strategy for qualitative analysis. Scand J Public Health; 40: 795-805.

Michel, K., Maltsberger, J.T., Jobes, D.A., Leenaars, A.A. Orbach, I., Stadler, K., Dey, P., Young, R.A., \&t Valach, L. (2002). Case study. Discovering the Truth in Attempted Suicide. Am J Psychoteraphy; 56 (3): 424-437 Mills, K.L., Lynskey, M., Teesson, M., Ross, J., \& Darke, S. (2005). Post-traumatic stress disorder among people with heroin dependence in the Australian treatment outcome study (AOS): prevalence and correlates. Drug Alcohol Depend; 77 (3): 243-249.

Möller-Leimkühler, A. M. (2003). The gender gap in suicide and premature death or: Why are men so vulnerable? Eur Arch Psychiatry Clin Neurosci; 253(1): $1-8$.

Oyefeso, A., Ghodse, H., Clancy, C., Corkey, J., \& Goldfinch, R. (1999). Drug abuse-related mortality: a study of teenage addicts over a 20-year period. Soc Psychiatry and Psychiatr Epidemiol; 34 (8): 437-441. Retterstøl, N., Ekeberg, Ø., \& Mehlum, L. (2002). Selvmord - et personlig og samfunnsmessig problem. Oslo: Gyldendal Norsk Forlag.

Scourfield, J. (2005). Suicidal Masculinities. Sociological Research Online; 10 (2). Lest 01.03.13 (http:// www.socresonline.org.uk/10/2/.html).

Skjervheim, H. (1976). Deltaker og tilskodar og andre essays. Oslo: Aschehoug forlag.

Trulsson, K. (2004). The role of social support when giving up a drug abuse: A female perspective. Int Soc Welfare; 13: 145-157.

World Health Organisation. (1986). Ottawa charter for health promotion. First international conference on health promotion. Lest 24.10.12 (http://www.who. int/healthpromotion/conferences/previous/ottawa/ en/print/html).

Yin, R.K. (2014). Case Study Research. Design and Methods (5h Ed). London: Sage. 